Tersedia Online di http://journal.unismuh.ac.id/index.php/otoritas

Otoritas : Jurnal Ilmu Pemerintahan, 6 (1), April 2016, 12-20

\title{
Pengembangan Kecamatan di Kabupaten Bandung Barat
}

\author{
Dewi Kurniasih $^{\left.1^{*}\right)}$, Yudi Rusfiana ${ }^{2}$ \\ ${ }^{1}$ Program Studi Ilmu Pemerintahan, Fakultas Ilmu Sosial dan Ilmu Politik, Universitas Komputer \\ Indonesia, Jl. Dipatiukur No. 116 Bandung, Jawa Barat, Indonesia, 40132 \\ 2Program Studi Manajemen Pembangunan, Fakultas Manajemen Pemerintahan, Institut \\ Pemerintahan Dalam Negeri, Jalan Raya Jatinangor Km 20 Sumedang, Jawa Barat, Indonesia, 45363
}

Diterima : 3 Februari 2016; Disetujui : 27 Maret 2016; Dipublikasikan 14 April 2016

\begin{abstract}
One of device regency is the subdistrict. Subdistrict as the technical regional programs, have work areas, led by Camat. When society still do not feel any equitable development results, it was natural to enter the 10 years, the West Bandung Regency Government planning subdistrict development strategy. The population is increasing, the sub-district government services should be improved. Geographical constraints and demands of society into its own problems in terms of a sub-district development. Subdistricts development is intended to increase the capacity of districts, especially in governance, development and public service. The purpose of this study is the recommendation several strategies development, especially in Lembang Subdistrict, Cipatat and Cipongkor in West Bandung Regency. The method used is descriptive method with qualitative approach through surveys. Data was collected through library research, observation and interviews. The results showed that all three subdistricts have met the basic requirements, technical and administrative measures to be developed. This is in accordance with the mandate of Government Regulation No. 19 Year 2008 regarding the District is still valid.
\end{abstract}

Keywords: development; subdistrict; public service

\begin{abstract}
Abstrak
Salah satu perangkat daerah kabupaten adalah kecamatan. Kecamatan sebagai pelaksana teknis kewilayahan, mempunyai wilayah kerja yang dipimpin oleh Camat. Ketika masyarakat belum merasakan adanya pemerataan hasil pembangunan, maka wajarlah memasuki 10 tahun, Pemerintah Kabupaten Bandung Barat merencanakan strategi pengembangan kecamatan. Jumlah penduduk semakin bertambah maka pelayanan pemerintah kecamatan harus ditingkatkan. Kendala geografis dan tuntutan masyarakat menjadi permasalahan sendiri dalam sebuah pengembangan kecamatan. Pengembangan kecamatan ditujukan untuk meningkatkan kapasitas kecamatan terutama dalam penyelenggaraan pemerintahan, pembangunan dan pelayanan publik. Tujuan penelitian ini adalah terekomendasinya beberapa strategi pengembangan khususnya pada Kecamatan Lembang, Cipatat dan Cipongkor di Kabupaten Bandung Barat. Metode yang digunakan adalah metode deskriptif dengan pendekatan kualitatif melalui survei. Teknik pengumpulan data dilakukan dengan studi pustaka, observasi dan wawancara. Hasil penelitian menunjukkan bahwa ketiga kecamatan tersebut telah memenuhi persyaratan dasar, teknis dan administratif untuk dikembangkan. Hal ini sesuai dengan amanah Peraturan Pemerintah No. 19 Tahun 2008 tentang Kecamatan yang masih berlaku.
\end{abstract}

Kata kunci : pengembangan; kecamatan; pelayanan publik

Cara Penulisan Sitasi : Kurniasih, D., Rusfiana, Y., (2016). Pengembangan Kecamatan di Bandung Barat. Otoritas : Jurnal Ilmu Pemerintahan, 6 (1), 12-20.

*)Penulis Korespondensi.

E-Mail : dekur010575@yahoo.com

Copyright (C) 2016, Otoritas : Jurnal Ilmu Pemerintahan, p-ISSN: 2088-3706, e-ISSN: 2502-9320 
Tersedia Online di http://journal.unismuh.ac.id/index.php/otoritas

Otoritas : Jurnal Ilmu Pemerintahan, 6 (1), April 2016, 13

\section{Pendahuluan}

Kabupaten Bandung Barat merupakan daerah otonom baru, hasil pemekaran dari Kabupaten induk yaitu Kabupaten Bandung sejak tahun 2007. Sampai saat ini, pengembangan Kabupaten Bandung Barat masih sangat diperlukan. Sementara itu, menurut PP No. 19 Tahun 2008 kecamatan merupakan perangkat daerah kabupaten sebagai pelaksana teknis kewilayahan yang mempunyai wilayah kerja tertentu yang dipimpin oleh Camat. Kaitannya dalam hal ini bahwa pengembangan wilayah kecamatan merupakan salah satu strategi yang ditetapkan oleh Pemerintah Kabupaten Barat. Pengembangan kecamatan ditujukan untuk meningkatkan kapasitas kecamatan terutama dalam penyelenggaraan pemerintahan, pembangunan dan pelayanan publik.

Sugeng (2005) menegaskan bahwa "Pengembangan wilayah setidak-tidaknya perlu ditopang oleh enam pilar/aspek, yaitu: (1) aspek biogeofisik, (2) aspek ekonomi, (3) aspek sosial dan budaya, (4) aspek kelembagaan, (5) aspek lokasi, dan (6) aspek lingkungan". Keenam aspek tersebut diharapkan menjadi pertimbangan sebuah wilayah bilamana akan dikembangkan.

Perencanaan pembangunan kecamatan merupakan bagian penting dari sebuah perencanaan pembangunan kabupaten. Saat ini, Kabupaten Bandung Barat memiliki 15 kecamatan yang tersebar di seluruh wilayahnya. Luas wilayah dengan sejumlah karakteristik kewilayahan baik dilihat dari aspek sosial, budaya dan ekonomi memiliki keanekaragaman, menjadikan wilayah kecamatan ini menjadi khas. Namun, sampai saat ini masyarakat masih belum merasakan adanya pemerataan hasil pembangunan. Dengan adanya pengembangan wilayah kecamatan ini diharapkan dapat memberikan outcomes yang positif terhadap kinerja pemerintahan baik dalam penyelenggaraan pemerintahan itu sendiri, pembangunan maupun pelayanan publik.

Teori kebijakan dan hasil penelitian yang ada, menunjukkan bahwa pengembangan kecamatan dapat dilakukan melalui pengembangan kewilayahan, penataan kewenangan dan peningkatan pembangunan fisik dan non fisik. Semua itu dapat dilakukan dengan harapan wilayah kecamatan dapat tumbuh, berkembang dan mampu menyelenggarakan fungsi pemerintahannya dalam kerangka otonomi daerah guna meningkatkan pelayanan publik secara optimal untuk mempercepat terwujudnya kesejahteraan masyarakat.

Adapun pengembangan wilayah kecamatan yang menjadi fokus kajian ini adalah Kecamatan Lembang, Kecamatan Cipatat dan Kecamatan Cipongkor. Hal ini dilakukan atas beberapa kondisi yang ada di masing-masing wilayah kecamatan tersebut.

Kecamatan Lembang yang berada di wilayah Bandung Utara, saat ini menjadi salah satu destinasi wisata di Kota Bandung. Setiap akhir pekan atau hari libur, wilayah ini selalu dikunjungi oleh para wisatawan. Selain udaranya yang sejuk, banyak objek wisata yang menarik dikunjungi. Alhasil kemacetan senantiasa terjadi di Lembang. Kecamatan Lembang berbatasan dengan Kota Bandung, Kabupaten Subang dan Kabupaten Bandung. Banyak penelitian telah dilakukan sebelumnya yang memberikan rekomendasi kecamatan ini layak untuk dimekarkan.

Kecamatan Cipatat memiliki luas wilayah yang luas. Jarak antar desanya sangat berjauhan, dan secara geografis bentuk wilayah ini mengitari Kecamatan Padalarang ditengahnya.

Sedangkan Kecamatan Cipongkor memiliki ibukota kecamatan yang sulit dijangkau desa-desa di wilayahnya. Bahkan lebih dekat ke ibukota kecamatan lainnya. Sehingga pelayanan publik pun kurang maksimal. Inilah beberapa alasan mengapa kajian ini penting dil- 
akukan.

Dalam beberapa penelitian terdahulu yang secara khusus membahas tentang pengembangan kecamatan dalam beberapa aspek penelitian. Gunamantha (2015) membahas tentang Analisis Dampak Program Pengembangan Kecamatan Terhadap Pengentasan Kemiskinan di Kabupaten Buleleng, dalam penelitian ini didapatkan temuan bahwa rangkaian kegiatan pengembangan kapasitas yang dilaksanakan dalam program pemberdayaan masyarakat PNPM Mandiri Pedesaan di Kecamatan Sawan dan Kecamatan Kubutambahan Kabupaten Buleleng telah menunjukkan perkembangan kapasitas masyarakat yang cukup baik, hal ini sesuai dengan teori yang menyatakan bahwa pemberdayaan menekankan pentingnya suatu proses edukatif atau pembelajaran dalam melengkapi masyarakat untuk meningkatkan keberdayaan mereka, sehingga masyarakat memiliki gagasangagasan, pemahaman, kosa kata, dan keterampilan bekerja menuju perubahan yang efektif dan berkelanjutan.

Wijaya (2016) juga meneliti mengenai pengembangan kecamatan dengan judul Pengembangan Kecamatan Kangoro sebagai Kawasan Agropolitan, hasil penelitian ini menemukan bahwa proses pelaksanaan pemberdayaan masyarakat desa berbasis agropolitan yang dimulai dari tahap perencanaan, sosialisasi, dan pelaksanaan program dapat dikatakan berhasil. Program yang agropolitan yang dilaksanakan sejak tahun 2007 sampai sekarang ini telah berdampak positif bagi masyarakat pedesaan, diantaranya semakin berkembangnya sumber daya manusia kelembagaan pertanian perdesaan, dan pengembangan kemitraan dalam proses yang semakin terarah.

Selanjutnya penelitian dari Arliansyah (2006) yang meneliti tentang Prospek Pengembangan Kecamatan Sebagai Motor Pertumbuhan Ekonomi dengan alat analisis yang digunakan adalah model gravitasi, LQ dan pendekatan ekonometrika. Dari analisis model gravitasi diketahui bahawa sebagian besar kecamatan mempunyai tingkat aksesbilitas yang lebih kuat terhadap pusat pertumbuhan Tembilahan dibanding pusat pertumbuhan yang lain. Berdasarkan kekuatan aksebilitas juga dapat dikelompokkan wilayah-wilayah hinterland bagi setiap pusat pertumbuhan. Dengan formula LQ diketahui bahwa Kecamatan Reteh memiliki sektor/sub sektor unggulan terbanyak, namun penyebaran sektor/sub sektor tidak merata antar kecamatan. Dari analisis model persamaan simultan diketahui bahwa variabel belanja pembangunan tidak berpengaruh langsung dan signifikan terhadap semua sektor perekonomian, begitu juga dengan variabel aksesbilitas. Sementara itu, nilai LQ masing-masing sektor berpengaruh signifikan terhadap sektornya, kecuali sektor transportasi dan komunikasi, serta jasa.

Berdasarkan beberapa penelitian terdahulu yang telah dijabarkan maka maksud dari penelitian pengembangan kecamatan ini diarahkan untuk menganalisa secara komprehensif tentang data dan potensi Kecamatan Lembang, Cipatat dan Cipongkor guna memberikan arah pengembangannya.

Sedangkan tujuan kajian ini adalah tersedianya data dan informasi terbaru tentang berbagai potensi kewilayahan dalam kerangka pengembangan Kecamatan Lembang, Cipatat dan Cipongkor, tersusunnya model pengembangan Kecamatan Lembang, Cipatat dan Cipongkor, terekomendasinya beberapa strategi pengembangan Kecamatan Lembang, Cipatat dan Cipongkor.

\section{Metode Penelitian}

Penelitian ini dilakukan di beberapa tempat yang menjadi fokus dari kajian penelitian ini yaitu Kecamatan 
Tersedia Online di http://journal.unismuh.ac.id/index.php/otoritas

Otoritas : Jurnal Ilmu Pemerintahan, 6 (1), April 2016, 15

Lembang, Kecamatan Cipatat dan Kecamatan Cipongkor. Hal ini dilakukan atas beberapa kondisi yang ada di masingmasing wilayah kecamatan tersebut. Metode yang digunakan adalah metode deskriptif dengan pendekatan kualitatif melalui survei. Teknik pengumpulan data dilakukan dengan studi pustaka, observasi dan wawancara.

\section{Hasil dan Pembahasan}

\subsection{Pengembangan wilayah Kecamatan Lembang}

Kondisi wilayah Lembang yang sejuk nan asri membuat Lembang menjadi salah satu destinasi wisatawan di Kota Bandung. Semakin hari jumlah wisatawan yang berkunjung ke Lembang semakin bertambah. Hal ini dikarenakan semakin banyak dibukanya objek-objek wisata di sekitar Lembang. Dampak yang dirasakan adalah kemacetan yang sangat padat menjelang akhir pekan di Kota Bandung. Beberapa pihak menyarankan bahwa Kecamatan Lembang sudah saatnya untuk dimekarkan, sepanjang memenuhi ketentuan-ketentuan perundangundangan serta didasari oleh efektifitas pelayanan terhadap masyarakat dapat tercapai.

Kemacetan di sekitar Lembang rupanya diakibatkan kurangnya area perparkiran di sekitar objek wisata. Sehingga dipandang perlu adanya sarana perparkiran modern untuk menyerap kendaraan di parkiran. Hal ini dimaksudkan agar sarana parkir yang sudah ada dapat lebih nyaman bagi para wisatawan yang berkunjung ke tujuan wisata Lembang.

Sektor pariwisata Lembang yang menjadi hunting area wisatawan, harus diikuti dengan pembinaan para Pedagang Kaki Lima (PKL) untuk wisata kulinernya. Selain itu, di kawasan Lembang perlu ada pelestarian penjagaan situs daerah, pengembangan seni keterampilan dan kerajinan, pendayagunaan lahan produktif, potensi komunitas dan organisasi untuk menunjang pengembangan program- program kecamatan. Hal di atas tentunya akan menjadikan jalan raya Lembang menjadi malioboronya Bandung Barat.

Hasil penelitian menunjukkan bahwa luas wilayah serta jumlah penduduk Lembang sudah dirasa memenuhi syarat untuk dimekarkan. Mengenai rencana pemekaran Pemerintah Kecamatan Lembang pada prinsipnya setuju saja, asalkan dapat masyarakat merasakan jangkauan atau jarak tempuh dari desanya masingmasing semakin mudah dan memperlancar masyarakat untuk segala bentuk pelayanan, jangan sampai menyulitkan masyarakat sebagai pengguna pelayanan kepada masyarakat.

Para tokoh masyarakat mendesak agar segera dilaksanakan pengembangan kecamatan, misalnya menjadi Kecamatan Lembang dan Kecamatan Maribaya. Pengembangan kecamatan diharapkan dapat menjadi tempat yang strategis yang lebih mudah menjangkau masyarakat.

Ruang lingkup wilayahnya bisa saja sama atau dalam hal ini dibagi dua sehingga masing-masing menjadi delapan desa. Jika benar akan dikembangkan jangan sampai adanya penurunan pelayanan kepada masyarakat apalagi menambah beban masyarakat. Jumlah desa yang sudah terlalu banyak dan besarnya jarak pelayanan desa ke kecamatan bagi desa yang jauh

Untuk pemekaran Kecamatan Lembang mohon dipercepat karena cakupan wilayah kecamatan induk terlalu besar dan apabila kecamatan baru terwujud maka sarana dan prasarana serta pelayanan masyarakat akan terlayani dengan cepat. Mengenai saluran air harus benarbenar disalurkan kemana arah pembuangan harus jadi bahan pemikiran karena dilokasi kecamatan ini sulit untuk menyalurkan pembuangan air.

Intinya Pemekaran suatu wilayah harus dikaji dengan baik, tentunya harus dikaitkan dengan pelayanan, kalau pelayanan itu akan lebih baik kenapa tidak, tetapi kalau lebih buruk dari sekarang, 
Tersedia Online di http://journal.unismuh.ac.id/index.php/otoritas

Otoritas : Jurnal Ilmu Pemerintahan, 6 (1), April 2016, 16

lebih baik diperbaiki saja yang ada. Pada prinsipnya pemekaran sebuah wilayah harus berorientasi kepada peningkatan pelayanan menuju ke arah yang lebih baik.

Dilihat dari persyaratan sebagaimana yang diterangkan dalam pasal $222 \mathrm{UU}$ No. 23 Tahun 2014 tentang Pemerintahan Daerah, dimana harus memenuhi persyaratan dasar, persyaratan teknis, dan persyaratan administratif, maka Kecamatan Lembang telah memenuhi persyaratan dasar untuk dibentuk kecamatan baru.

Hal tersebut dapat dilihat dari jumlah penduduk Lembang 170.653 Jiwa. Jumlah penduduk Kecamatan Lembang sudah lebih dari cukup untuk dilakukan pengembangan. Berikutnya adalah luas wilayah Lembang yaitu seluas 10620 ha, telah memenuhi syarat luas wilayah. Lalu jumlah minimal desa/kelurahan yang dimana kecamatan lembang sudah memenuhi persyaratan, Kecamatan Lembang memiliki 16 desa dari minimal 10 desa yang dipersyaratkan. 16 desa di kecamatan Lembang apabila dibagi dua, komposisinya adalah : 10 desa untuk kecamatan induk, dan 6 desa untuk kecamatan baru (yang dimekarkan). Tetapi, berdasarkan hasil diskusi, dari 16 Desa dapat dibagi dua menjadi 8 desa di Kecamatan Induk dan 8 Desa di Kecamatan baru, dan sisa 2 desa dari Kecamatan lain. Terakhir yang harus dipenuhi dalam persyaratan dasar adalah usia minimal 5 tahun, Kecamatan Lembang dan desa yang dinaunginya memiliki usia yang lebih dari 5 tahun.

Dari persyaratan teknis dapat diketahui bahwa Kecamatan Lembang telah memenuhi keseluruhan persyaratan teknis seperti kemampuan keuangan daerah, sarana dan prasana pemerintahan, dan persyaratan teknis lainnya yang diatur dalam ketentuan peraturan perundang- undangan.

Namun dilihat dari persyaratan administrasi, Kecamatan Lembang belum memenuhi persyaratan dasar untuk dibentuk kecamatan baru. Hal tersebut dapat dilihat dari kesepakatan musyawarah desa dan/atau keputusan forum komunikasi kelurahan atau nama lain di Kecamatan lembang belum ditentukan.

\subsubsection{Pengembangan Wilayah Kecama- tan Cipatat}

Berdasarkan hasil FGD dengan tokoh masyarakat, dipandang sangat perlu diadakan pengembangan Kecamatan Cipatat. Hal ini dikarenakan potensi wilayah secara geografis, dengan jumlah maksimal 10 desa dalam/kecamatan dapat menyeimbangkan tentang semua sektor, pelayanan masyarakat akan dapat mudah selesai dan dengan mudah terlayani.

Kecamatan Cipatat setuju untuk dimekarkan, karena Desa Sumur Bandung dan Nyalindung secara geografis sangat jauh dari ibukota Kecamatan Cipatat saat ini. Oleh karenanya, untuk pengembangan Kota Walini di Desa Sumurbandung dan Desa Mandalasari akan lebih baik ada di satu wilayah admiistratif yang sama.Mengenai nama kecamatan baru secara historis lebih baik bernama Kecamatan Nyalindung. Pengembangan/ pemekaran kecamatan Cipatat menjadi kecamatan yang baru diharapkan membuat segala bentuk pelayanan bagi masyarakat sangat mudah baik dari segi akses/sarana mampu dari kemudahan dalam memperoleh informasi mengenai pelayanan administrasi. Masyarakat tentu mendambakan pelayanan mudah dan murah serta efisien.

Mewakili RW 15 dan RW 09 dapat dimekarkan, alasannya kalau mau ke kecamatan sangat jauh sekali jarak tempuh, wilayah Rw 15 kurang lebih 30km untuk kebutuhan yang dilakukan ke kecamatan yang ada sekarang. Selain jarak ke Kecamatan Cipatat terlalu jauh, terlambatnya informasi dari kecamatan serta guna mempermudah pelayanan, dimohon untuk Kecamatan Nyalindung segera dilaksanakan secepatnya. 
Sebagai warga masyarakat Desa Nyalindung sangat setuju dengan adanya pemekaran Kecamatan Desa Nyalindung menjadi kota kecamatan. Karena kami sebagai warga masyarakat merasa terhambat dengan akses ke kecamatan induk karena sangat strategis dari desa nyalindung. Kami mohon bukan hanya opini publik karena kami butuh keseriusan bukan hanya opini belaka. Persetujuan warga dengan adanya pembentukan kecamatan baru mengingat jauhnya fasilitas kecamatan yang sudah ada sangat memberatkan masyarakat terutama biaya transportasi dan waktu sangat tidak efektif karena sangat jauhnya kecamatan yang ada. Mereka sudah memimpikan dari tahun 1982. Cakupan wilayah kecamatan dapat disesuaikan dengan jangkauan/ jauh desa.

Pengembangan Kecamatan Cipatat diharapkan akan diikuti dengan tersedianya fasilitas dan sarana dan kecukupan pelayanan masyarakat serta kondusifitas sosial ekonomi yang dapat menunjang terselenggaranya pemerintah kecamatan yang baik sesuai dengan visi KBB yaitu cermat.

Kajian mengenai pengembangan kecamatan ini berharap lembaga ini cepat meloloskan program pengembangan kecamatan nyalindung tersebut. Pengaruh dengan kecamatan baru sangatlah membantu terhadap masyarakat terutama bentuk pelayanan yang sangat cepat dan praktis. Mengharapkan para birokrat dapat mencetak para pemimpin di wilayah tersebut, pemimpin yang inovating, tidak terjegal wilayah yang kaya program tapi sangat miskin implementasinya. Nantinya para birokrat yang punya otoritas untuk bernawaitu untuk berkreasi dan terobosan-terobosan yang lebih baik. Apalagi pemerintah daerah punya anggaran yang besar bagi kesejahteraan masyarakat. Sebuah impian kami sebagai warga masyarakat Nyalindung. Alhamdulillah 10 desa sangat setuju pembentukan kecamatan di Desa Nyalindung.
Dilihat dari persyaratan yang ada maka Kecamatan Cipatat telah memenuhi persyaratan dasar untuk dibentuk kecamatan baru. Hal tersebut dapat dilihat dari jumlah penduduk minimal, dimana jumlah penduduk Kecamatan Cipatat berada diangka 123.285 Jiwa dan lebih dari cukup sesuai apa yang dipersyaratkan.

Begitu pula dengan luas wilayah, dimana Kecamatan Cipatat memiliki luas wilayah seluas 10.320 ha, luas wilayah yang telah memenui persyaratan. Sedangkan bila dilihat dari jumlah minimal desa yang menjadi cakupan, maka berdasarkan data kecamatan, Berdasarkan cakupan wilayah sesuai dengan ketentuan, dapat dinyatakan bahwa Kecamatan Cipatat memenuhi syarat untuk dilakukan pengembangan karena jumlah desa yang ada di wilayah Kecamatan Cipatat yang berjumlah 12 desa dengan 9 desa untuk kecamatan induk dan 3 desa untuk kecamatan baru. Pada kecamatan baru 7 desa dari 4 kecamatan yang berbatasan yaitu Desa Bojongkoneng Kecamatan Ngamprah; Desa Cipada, Desa Mandalasari dan Desa Mekarjaya dari Kecamatan Cikalongwetan; Desa Cempakamekar dan Desa Tagogapu dari Kecamatan Padalarang; Desa Sadangmekar dari Kecamatan Cisarua. Begitu pula dengan usia minimal, usia kecamatan dan desa sekitarnya sudah lebih dari 5 tahun.

Dilihat dari persyaratan teknis, Kecamatan Cipatat telah memenuhi persyaratan dasar untuk dibentuk kecamatan baru. Hal tersebut dapat dilihat dari kemampuan keuangan Daerah, sarana dan prasarana pemerintahan yang dimiliki Kecamatan Cipatat yang lengkap, dan persyaratan teknis lainnya yang diatur dalam ketentuan peraturan perundang- undangan.

Dilihat dari persyaratan administrasi, Kecamatan Cipatat sudah memenuhi persyaratan dasar untuk dibentuk kecamatan baru. Telah dilakukan kesepakatan musyawarah Desa dan/atau keputusan forum komunikasi kelurahan atau nama 
Tersedia Online di http://journal.unismuh.ac.id/index.php/otoritas

Otoritas : Jurnal Ilmu Pemerintahan, 6 (1), April 2016, 18

lain di Kecamatan induk dan Kecamatan yang akan dibentuk.

\subsection{Pengembangan Wilayah Kecama- tan Cipongkor}

Hasil FGD bersama tokoh masyarakat di Kecamatan Cipongkor adalah persetujuan warga apabila ada wacana pengembangan kecamatan dengan alasan letak geografis antar desa dan pelayanan publik dapat terakomodir dengan baik. Guna lebih mengefektifkan pelaksanaan program-program dalam meningkatkan pelayanan terhadap masyarakat di perdesaan dan alangkah baiknya pengembangan kecamatan ini ditindaklanjuti dengan kelengkapan-kelengkapan dinas/ instansi yang sangat penting yaitu antara lain kantor Koramil dan kantor Polsek dan lain-lain untuk mencapai hari esok yang lebih baik.

Kecamatan Cipongkor yang ada sekarang letaknya jauh dari beberapa desa, dikarenakan apabila ada keperluan membuat surat-surat agak terlambat karena jauh jarak tempuh juga jalannya sangat rusak. Semoga dengan adanya pengembangan kecamatan ini bisa lebih meningkatkan pelayanan terhadap masyarakat. Segera direalisasikan sehubungan dengan kebutuhan yang amat mendesak.

Penataan wilayah di suatu kabupaten merupakan suatu kebutuhan yang mutlak untuk mencapai kemajuan yang dicita-citakan masyarakat Bandung Barat. Masalah tempat dan nama kecamatan baru harus didiskusikan lagi. Sambutan masyarakat sangat baik, karena yang selama ini mau ke kecamatan saja jauh sekali. Mudah-mudahan pelayanan tidak hanya wacana melainkan realita nyata sehingga mereka yang selama ini perlu ke kecamatan mudah-mudahan menjadi dekat dan terakomodir serta perubahan kesejahteraan bagi masyarakat pada umumnya.

Usulan nama kecamatan baru adalah Kecamatan Cibeureum. Terbentuknya kecamatan baru yang lokasinya tidak jauh dari Desa Karanganyar, karena karangan- yar adalah salah satu desa yang sangat kurang mendapat perhatian dari pemerintah di atasnya, mereka sangat berharap dengan adanya kecamatan baru yang memiliki lokasi strategis menjadi sebuah harapan masyarakat desa Karanganyar.

Pengembangan Kecamatan Cipongkor ini ada juga menjadi "Kecamatan Cijenuk". Pembenahan infrastruktur terutama akses jalan, pembentukan polsek, pembentukan koramil, pembentukan kantor pos. Nama kecamatan harus identik dengan identitas nama desa dan harus ada nilai kepemimpinan pemerintah KBB. Kantor kecamatan baru lebih cocok di Desa Citalem untuk menjawab rentang kendali pelayanan karena citalem berada di tengah-tengah.

Dilihat dari persyaratan di atas Kecamatan Cipongkor telah memenuhi persyaratan dasar untuk dibentuk kecamatan baru. Hal tersebut dapat dilihat dari jumlah penduduk minimal, dimana Kecamatan Cipongkor memiliki jumlah penduduk sebesar 123.285 Jiwa, jumlah penduduk tersebut telah memenuhi batas minimal pembentukan kecamatan. Dilihat dari luas wilayah, luas wilayah Kecamatan Cipongkor seluas 6.304.527 ha sangat mememenuhi batas luas wilayah yang dipersyaratkan.

Selain itu bila ditilik dari Jumlah minimal Desa/kelurahan yang menjadi cakupan. Berdasarkan data kecamatan, Berdasarkan cakupan wilayah sesuai dengan ketentuan, dapat dinyatakan bahwa Kecamatan Cipongkor memenuhi syarat untuk dilakukan pengembangan karena jumlah desa yang ada di wilayah Kecamatan Cipongkor yang berjumlah 14 desa, sehingga apabila dimekarkan tentunya akan memenuhi ketentuan cakupan wilayah 10 desa. 14 desa di kecamatan Cipongkor apabila dibagi dua, komposisinya adalah : 7 desa untuk kecamatan induk, dan 7 desa untuk kecamatan baru (yang dimekarkan) ditambah 3 dari Kecamatan yang berbatasan. Lalu usia mini- 
Tersedia Online di http://journal.unismuh.ac.id/index.php/otoritas

Otoritas : Jurnal Ilmu Pemerintahan, 6 (1), April 2016, 19

mal lima tahun yang telah dipenuhi oleh kecamatan ini.

Dilihat dari persyaratan teknis, Kecamatan Cipongkor telah memenuhi persyaratan untuk dibentuk kecamatan baru. Hal tersebut dapat dilihat dari kemampuan keuangan Daerah, sarana dan prasarana pemerintahan yang dimiliki Kecamatan Cipongkor serta persyaratan yang dipersyaratkan oleh peraturan yang ada.

Begitu pula ketika dilihat dari persyaratan administrasi, Kecamatan Cipongkor sudah memenuhi persyaratan dasar untuk dibentuk kecamatan baru. Hal tersebut dapat dilihat dari : adanya kesepakatan musyawarah desa dan/atau keputusan forum komunikasi desa atau nama lain di Kecamatan Cipongkor. Berdasarkan hasil diskusi dengan jajaran kecamatan Cipongkor dan BPD di seluruh desa di Kecamatan Cipongkor, dapat disimpulkan bahwa sebagian besar menyatakan bahwa lokasi ibu kota kecamatan yang dimekarkan (kecamatan baru) adalah di desa Cijenuk, dinilai memiliki aksesibilitas, keterjangkauan, posisi geografis, dan infrastruktur yang relatif memadai. Namun demikian, tentunya diperlukan kajian lebih lanjut apabila memang Kecamatan Cipongkor sudah memenuhi syarat untuk dimekarkan.

\section{Kesimpulan}

Berdasarkan hasil dan pembahasan sebelumnya, dapat disimpulkan bahwa:

1. Data dan informasi terbaru tentang berbagai potensi kewilayahan yang ada di Kecamatan Lembang, Cipatat dan Cipongkor sudah tersedia. Hal ini dapat menjadi identifikasi awal manakala pengembangan kecamatan akan dilaksanakan pada ketiga kecamatan tersebut.

2. Model Pengembangan Kecamatan Lembang, Cipatat, dan Cipongkor dapat dilakukan dengan memperhatikan potensi dan rencana tata ruang pada ketiga kecamatan tersebut.
3. Berdasarkan persyaratan dasar, teknis dan administratif sesuai amanah Undang-Undang, maka pengembangan Kecamatan Lembang , Cipatat, dan Cipongkor dapat dilakukan.

Menindaklanjuti kesimpulan yang telah dijabarkan, kami rekomendasikan beberapa hal sebagai berikut :

1. Lakukan sosialisasi tentang pengembangan kecamatan secara intensif kepada masyarakat di wilayah Kecamatan Lembang, Cipatat dan Cipongkor.

2. Inventarisir kebutuhan masyarakat secara legalitas formal yang mendukung pengembangan ketiga kecamatan ini.

3. Lakukan pemetaan kewilayahan kecamatan berbasis web yang memudahkan penentuan calon ibukota kecamatan yang baru dengan menampilkan segala potensi-potensi unggulan yang ada pada masing-masing kecamatan pengembangan seperti tampak pada gambar 1 .

4. Ajukanlah pengembangan Kecamatan Lembang, Cipatat, dan Cipongkor, sebagai masukan dalam hak inisiatif Dewan Perwakilan Rakyat Daerah (DPRD) Kabupaten Bandung Barat.

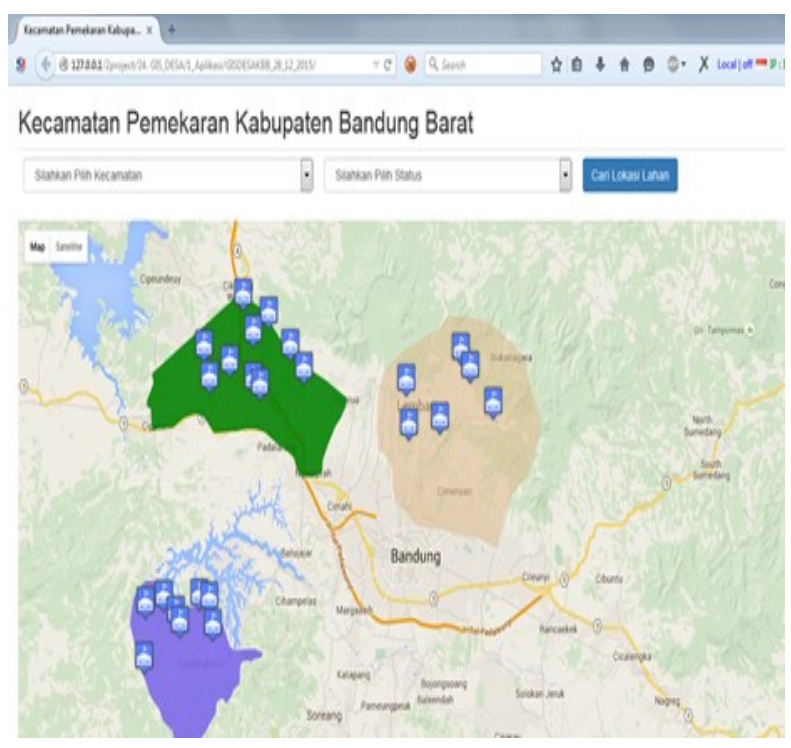

Gambar 1. Pemetaan Potensi Pengembangan Kecamatan 
Tersedia Online di http://journal.unismuh.ac.id/index.php/otoritas

Otoritas : Jurnal Ilmu Pemerintahan, 6 (1), April 2016, 20

\section{Ucapan Terima Kasih}

Terima kasih kami haturkan kepada Civitas Akademika Program Studi Ilmu Pemerintahan, Fakultas Ilmu Sosial dan Ilmu Politik, universitas komputer Indonesia dan Program Studi Manajemen Pembangunan, Fakultas Manajemen Pemerintahan, Institut Pemerintahan Dalam Negeri atas bantuan, dukungan dan atensinya dalam proses penelitian dan penulisan artikel ilmiah ini.

\section{Daftar Pustaka}

Arliansyah, A. (2006). Prospek Pengembangan Kecamatan sebagai Motor Pertumbuhan Ekonomi. Jurnal Kebijakan Ekonomi, 1 (3), 285-302.
Gunamantha, I. M. (2015). Analisis Dampak Program Pengembangan Kecamatan Terhadap Pengentasan Kemiskinan di Kabupaten Buleleng. Jurnal Ilmu Sosial dan Humaniora, 4(1), 523-533.

Sugeng, B. (2005). Teknik Analisis Pembangunan Wilayah Pesisir dan Lautan. Jakarta: PT. Pradnya Paramita.

Wijaya, W. (2016). Pengembangan Kecamatan Kangoro Sebagai Kawasan Agropolitan. Jurnal Administrasi Publik. 4 (4), 1-10. 